\title{
Article \\ Rheological Study of an Extruded Fish Diet with the Addition
of Hydrolyzed Protein Flour
}

\author{
José Luis Hoyos-Concha ${ }^{1}$, Héctor Samuel Villada-Castillo ${ }^{2}$, Alejandro Fernández-Quintero ${ }^{3}$ \\ and Rodrigo Ortega-Toro $4, *$ (i)
}

Citation: Hoyos-Concha, J.L.;

Villada-Castillo, H.S.;

Fernández-Quintero, A.;

Ortega-Toro, R. Rheological Study of an Extruded Fish Diet with the

Addition of Hydrolyzed Protein

Flour. Appl. Sci. 2021, 11, 8105.

https://doi.org/10.3390/app11178105

Academic Editor: Antonio Valero

Received: 31 July 2021

Accepted: 25 August 2021

Published: 31 August 2021

Publisher's Note: MDPI stays neutral with regard to jurisdictional claims in published maps and institutional affiliations.

Copyright: (c) 2021 by the authors. Licensee MDPI, Basel, Switzerland. This article is an open access article distributed under the terms and conditions of the Creative Commons Attribution (CC BY) license (https:/ / creativecommons.org/licenses/by/ $4.0 /)$.
1 Agroindustry Department, Agroindustrial Byproducts Exploitation Research Group (ASUBAGROIN), Universidad del Cauca, Popayán, Cauca 190003, Colombia; jlhoyos@unicauca.edu.co

2 Agroindustry Department, Research Group of Science and Technology of Agroindustrial Interest Biomolecules (CYTBIA), Universidad del Cauca, Popayán, Cauca 190003, Colombia; villada@unicauca.edu.co

3 School of Food Engineering, Research Group in Agri-Food and Biotechnological Process Engineering (GIPAB), Universidad del Valle, Cali, Valle del Cauca 760032, Colombia; alejandro.fernandez@correounivalle.edu.co

4 Food Engineering Department, Food Packaging and Shelf Life Research Group (FP\&SL) and Complex Fluids Engineering and Food Rheology Research Group (IFCRA), Universidad de Cartagena, Cartagena de Indias, Bolívar 130001, Colombia

* Correspondence: rortegap1@unicartagena.edu.co

\begin{abstract}
The extrusion of food for human and animal consumption is a unit operation that includes mixing, shearing, and force to the materials related to the rheological properties of the materials in the extruder. The present work aims to study the rheological behavior of an extruded fish diet incorporating hydrolyzed protein flour (HPF) processed by extrusion. The measurement was carried out online with a slit die rheometer, defining the rheological models and parameters that fit the process. During the extrusion process, the raw materials used were hydrolyzed protein flour, fish meal, and cassava starch. For the results, the evaluated treatments were adjusted to the Power Law, where an increase in the shear rate decreases the viscosity of the material, corresponding to a pseudoplastic behavior. The incorporation of hydrolyzed protein flour presented a significant effect on the value of $\mathrm{n}$ and $K_{l p}$, increasing the viscosity with the increase in the percentage of inclusion of HPF. The models obtained for the prediction of the viscosity are adjusted to the system's changes in shear rate, temperature, and humidity. The importance of the study lies in the fact that the diet developed can be applied to feed fish, and production is currently being scaled up to pilot plants for direct use by some producer communities.
\end{abstract}

Keywords: hydrolyzed protein flour; cassava starch; in-line rheology; power law; pseudoplastic

\section{Introduction}

The extrusion cooking of food for human and animal consumption is a unitary operation in which various products are produced from starchy raw materials, animal or vegetable origin, and oilseeds. Products for animal feed, especially for fish farming, are an example of these extruded products, which under high temperature and short time cooking conditions (HTST), mixing, shearing, and forcing the materials are carried out through a nozzle designed to form the product, processes strongly related to the rheological properties of the materials in the extruder [1].

Since the raw materials used in animal diets have different rheological properties, their understanding can facilitate the optimization of processing methods, process control, and product quality, as well as the quality of the finished product, such as texture, flavor release, stability, appearance, among others [2]. Apparent viscosity is one of the most important rheological properties of raw materials of non-Newtonian biological origin, being a variable used for the engineering analysis of extrusion [3], mainly in aspects of the behavior of the fluid during processing. Viscosity is related to composition and process variables during extrusion [4]. 
In extrusion processes, structural changes of the components occur since biopolymers such as starch and proteins are susceptible to high temperatures or mechanical stress [5]. Under suitable conditions, this increases the digestibility of the macromolecules [6]. The starch generates an increase in gelatinization and breakdown of its chains forming dextrins, and the proteins take place the unfolding of their structure and breaking of intermolecular bonds yielding peptides of different molecular weight, establishing molecular interactions between terminal groups of the protein and starch molecules. These changes that occur during the extrusion process affect the behavior of the fluid and can be measured, facilitating product quality assurance.

Different techniques have been used to carry out rheological measurements, which vary according to whether the determination is carried out off-line or in-line. In the first case, the experimental conditions can be applied mainly through capillary rheometers; these measurements are made with higher water contents, so the determined viscosity is lower than that developed directly in an extruder [7]. With in-line measurement systems, measurement is performed by coupling a device to the extruder outlet [7-12], achieving measurements that avoid structural changes and water loss during the height [13]. Both the cylindrical-type die (rod die) and the slit-type die (slot die) can be directly coupled to the extruder, achieving different shear rates with the screw speed, achieving broader ranges of shear rate [14,15]. Regardless of the technique used to determine the rheological behavior under extrusion firing, it has been established that molten materials are essentially pseudoplastic whose rheological behavior can be adequately adjusted to a Power Law model $[1,15,16]$. The first rheological model proposed to explain the behavior of cereal masses melted by extrusion was Harper's [9], which assumes that the group behaves as a pseudoplastic fluid, according to the Power Law model, with dependence on change in temperature of the Arrhenius type and an exponential sensitivity to change in water content [7].

The present work aims to study the rheological behavior of an extruded fish diet incorporating hydrolyzed protein flour processed by extrusion. The measurement was carried out in-line with a slit die rheometer, defining the rheological models and parameters that fit the process through the methods mentioned above to obtain real processing conditions for future scaling, determine the effect on the viscosity of the hydrolyzed protein system, and adjust a model of the system.

\section{Materials and Methods}

\subsection{Raw Materials}

The raw materials used for the evaluation during the extrusion process were hydrolyzed protein flour, fish flour (Siquality SA, Guayaquil, Ecuador), and cassava starch (Sucre starch); their chemical composition is described in Table 1. Additives such as vitamin core formulated for fish farming (Premex), Bentonite (Premex), calcium carbonate $\left(\mathrm{CaCO}_{3}\right)$ (analytical grade 99\%, Carlo Erba), and sodium chloride $(\mathrm{NaCl})$ (analytical grade 99\%, Carlo Erba, Chau. du Vexin, France) were incorporated into the diet.

Table 1. Chemical composition of raw materials on a dry basis (d.b.).

\begin{tabular}{cccc}
\hline Analysis & HPF & Fish Flour & Cassava Starch \\
\hline Moisture $(\%, \mathrm{~m} / \mathrm{m})$ & $5.05 \pm 0.02$ & $5.15 \pm 0.08$ & $12.86 \pm 0.03$ \\
Total protein $(\%, \mathrm{~m} / \mathrm{m})$ & $62.92 \pm 0.05$ & $63.20 \pm 0.06$ & $1.60 \pm 0.05$ \\
Ethereal extract $(\%, \mathrm{~m} / \mathrm{m})$ & $6.45 \pm 0.02$ & $6.81 \pm 0.02$ & 0 \\
Ashes $(\%, \mathrm{~m} / \mathrm{m})$ & $17.86 \pm 0.12$ & $18.67 \pm 0.14$ & 0 \\
Fiber $(\%, \mathrm{~m} / \mathrm{m})$ & $0.6 \pm 0.2$ & $1.0 \pm 0.2$ & $2.16 \pm 0.04$ \\
Nitrogen-free extract $(\mathrm{ELN})(\%, \mathrm{~m} / \mathrm{m})$ & 12.2 & 10.3 & 96.24 \\
Degree of hydrolysis $(\%, \mathrm{~m} / \mathrm{m})$ & $62.948 \pm 0.011$ & $5.61 \pm 0.05$ & \\
Soluble protein $(\%, \mathrm{~m} / \mathrm{m})$ & $68.94 \pm 0.09$ & $17.33 \pm 0.06$ & \\
\hline
\end{tabular}




\subsection{Diet Formulation}

HPF incorporation was evaluated in a range between 15 and 35\% as a substitute for fish meals. The starch source, vitamin nucleus, and minerals remained stable (Table 2) and were supplemented according to the requirements reported by the National Research Council.

Table 2. Raw materials are required for the preparation of the diet.

\begin{tabular}{cc}
\hline Raw Materials & Inclusion (\%) \\
\hline Cassava starch & 55.0 \\
Hydrolyzed protein flour & $15.0-35.0$ \\
Fish flour & $25.0-5.0$ \\
Vitamin nucleus & 2.0 \\
Calcium carbonate & 0.8 \\
Bentonite & 1.7 \\
Sodium chloride & 0.5 \\
\hline
\end{tabular}

Isoprotein and isoenergetic diets were obtained, formulated for omnivorous fish in the fattening stage. The flours were sieved through a Tyler series No. 40 sieves and mixed in a Kitchen Aid mixer for $30 \mathrm{~min}$. Later, they were packed in polyethylene bags and refrigerated for $24 \mathrm{~h}$ to be evaluated.

\subsection{Rheological Measurement Using an In-Line Slit Die Rheometer}

A Thermo Scientific (Haake ${ }^{\mathrm{TM}}$, MiniLab II, Dreieich, Germany) brand slit dies to type vertical line rheometer was used to measure the rheological properties of mixtures, including hydrolyzed protein flour, with an outlet opening of $1.5 \times 20 \mathrm{~mm}$, with ports for a melt temperature sensor and three pressure sensors (700, 500, and 300 bar) (see Figure 1), coupled to a compact single screw extruder (Haake Polylab OS Rheomex 19/25 OS, Dreieich, Germany), which consists of a $475 \mathrm{~mm}$ long (L) and $19 \mathrm{~mm}$ diameter (D) worm with a 25: $1 \mathrm{~L} / \mathrm{D}$ ratio, a maximum working temperature of $450^{\circ} \mathrm{C}$, a maximum speed of $250 \mathrm{~min}^{-1}$, and a maximum torque of $160 \mathrm{Nm}$, coupled to a Haake RheoDrive 4 system, with a motor power of $4 \mathrm{~kW}$. The feeding was carried out using the Haake Metering Feeder OS.
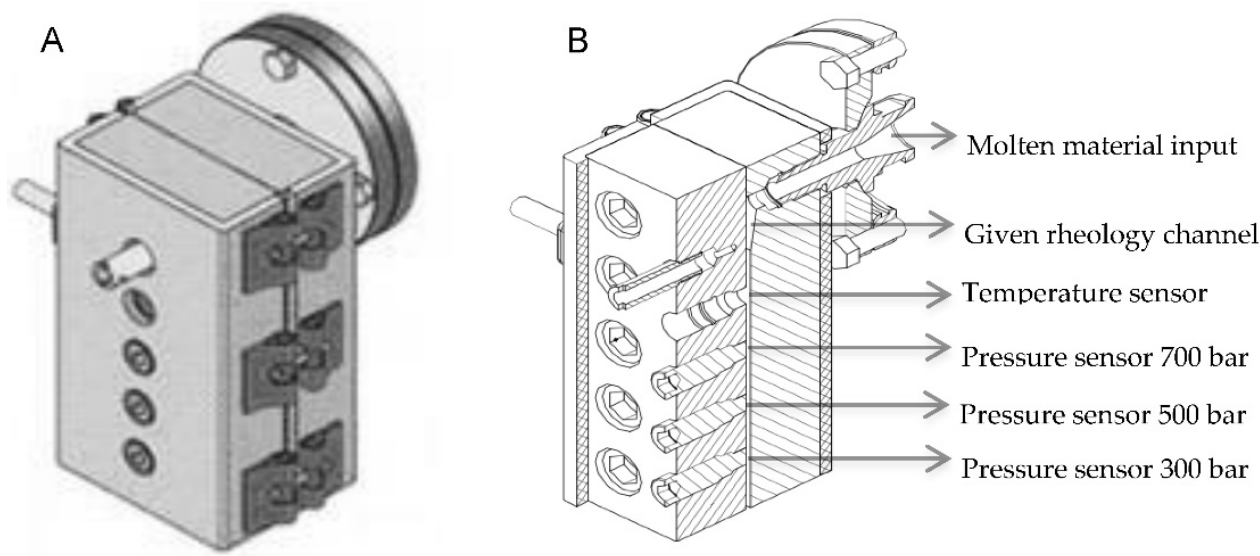

Figure 1. In-line slit die rheometer (A). General view (B). Longitudinal cut. Source: Adapted from Thermo Scientific.

The temperature and the range of working speeds were adjusted between 160 and $250 \mathrm{~min}^{-1}$, obtaining four samples $(160,190,220$, and 250), which were weighed, and the values were recorded in the PolySoft OS Capillary Rheology software for MS Windows.

The determination of the volumetric flow rate was carried out by quantifying the density of the melt. According to the ASTM D1238-2004c standard, the measurement was carried out in a Tinius Olsen model MP 1200 (Germany) plastometer, composed of a vertical cylinder, a die with a $2.095 \mathrm{~mm}$ hole diameter and $8 \mathrm{~mm}$ long. The test temperature was 
adjusted to $115{ }^{\circ} \mathrm{C}$ with $3.6 \mathrm{~kg}$ of weight on the piston, with a preheating time of $30 \mathrm{~s}$. The travel meter was adjusted to $6.35 \mathrm{~mm} \pm 0.25 \mathrm{~mm}$, the plastometer was loaded with an $8 \mathrm{~g}$ sample, the sample was made to flow through the die, and the weight was recorded for five examples for each material, obtaining the values of volumetric melt index, mass melt index, and melt density. According to the following equations, the parameters evaluated were shear rate, shear stress, and apparent viscosity [17].

$$
\gamma_{a p p}=\frac{6 \cdot Q}{W \cdot H^{2}}
$$

where $s \gamma_{a p p}{ }^{-1}$ is the apparent shear rate, $Q$ is the volumetric flow rate $\left(\mathrm{m}^{3} / \mathrm{s}\right), W$ is the width of the slit (m), and $H$ is the height of the slit (m) (Equation (1)).

$$
\tau=\frac{\Delta P \cdot H}{2 \cdot L}
$$

where $\tau$ is the shear stress $(\mathrm{Pa}), \Delta P$ is the pressure variation in the capillary $(\mathrm{Pa}), L$ is the length of the cleft (m), and $H$ is the height of the slit (m) (Equation (2)).

$$
\gamma_{\text {true }}=\frac{1}{3} \cdot \gamma_{a p p} \cdot\left(2+\frac{\partial \log \gamma_{a p p}}{\partial \log \tau}\right)
$$

$\gamma_{\text {true }}$ is the cutting speed. The correction of the shear rate was performed using the Weissenberg-Rabinowitsch equation (Equation (3)).

$$
\eta_{\text {app }}=\frac{\tau}{\gamma_{\text {true }}}
$$

$\eta_{\text {app }}$ is the apparent viscosity (Pa-s) quantified as the relationship between shear stress and true shear velocity (Equation (4)).

The rheological behavior of the samples was represented by the Power Law $(l p)$, Bingham (bg), and Casson (cs) models (Equations (5)-(7)).

$$
\begin{gathered}
\tau=K_{l p} \gamma^{n} \\
\tau=\tau_{0 b g}+K_{b g} \gamma \\
\tau^{0.5}=\tau_{0 c s}^{0.5}+K_{c s} \gamma^{0.5}
\end{gathered}
$$

where $K_{l p}, K_{c s}$, and $y K_{b g}$ are the consistency indices of the samples; they correspond to the minimum force to initiate the flow through the capillary $\tau_{0}$ [18].

The selected model was made according to the standard error (Equation (8))

$$
\left[\Sigma\left(X_{m}-X_{c}\right)^{2} /(N-2)^{2}\right]^{0.5} / \text { rango } \times 1000
$$

where $X_{m}$ is the measured value, $X_{c}$ is the calculated value, $N$ is the number of replicates, and range is the maximum value-minimum value of $X_{m}$.

\subsection{Statistical Analysis}

A $3 \mathrm{k}$ factorial design was used where the factors temperature, humidity, and inclusion of HPF were evaluated with three levels each, as described in Table 3. The results of the factorial design were analyzed by analysis of variance with a value of $p<0.05$, and the data were processed in the Minitab V.16 software. A mean comparison analysis was performed with the Tukey test at $p<0.05$ for statistically significant data.

$$
\eta=K_{l p} \cdot \gamma^{n-1} \cdot \exp \left[\frac{\Delta E}{R} \cdot\left(\frac{1}{T}\right)+b \cdot(M C)\right]
$$


Table 3. Factorial design $3^{3}$ applied to rheological evaluation.

\begin{tabular}{cc}
\hline Factors & Levels \\
\hline \multirow{2}{*}{ Temperature $\left({ }^{\circ} \mathrm{C}\right)$} & 115 \\
& 125 \\
& 135 \\
\hline \multirow{2}{*}{ Moisture $(\%)$} & 20 \\
& 22 \\
Hydrolyzed protein flour $(\%)$ & 24 \\
\hline
\end{tabular}

The experimental values obtained were adjusted to Harper's rheological regression model (Equation (9)). $\eta$ is the apparent viscosity $(\mathrm{Pa} \cdot \mathrm{s}), K_{l p}$ is the consistency index $\left(\mathrm{Pa} \cdot \mathrm{s}^{\mathrm{n}}\right)$, $n$ is the flow behavior index, $\gamma$ is the shear rate $\left(\mathrm{s}^{-1}\right), \Delta E$ is the activation energy $(\mathrm{J} / \mathrm{mol})$, $\Delta E$ is the constant ideal gases $(\mathrm{J} / \mathrm{mol} \mathrm{K}), T$ is the temperature $(\mathrm{K})$, and $M C$ is the mass fraction of water (w.b.). The parameter $b$ relates to the change in moisture content in the viscosity of the material.

\section{Results}

\subsection{Rheological Behavior Models}

The density values in the molten state at different percentages of hydrolyzed protein flour $(\mathrm{HPF})$ are presented in Table 4 . The results $(p<0.05)$ did not show significant differences. Therefore, the mean melt density of $1.176 \mathrm{~g} / \mathrm{cm}^{3}$ was used to calculate the volumetric flow rate and the corresponding determination of the shear rate $(\gamma)$ in the evaluated treatments. The density obtained was lower than that obtained by researchers [19], who reported a density of $1.253 \mathrm{~g} / \mathrm{cm}^{3}$ in starch mixtures and isolated soy protein in different percentages.

Table 4. Density values in the fade state.

\begin{tabular}{cc}
\hline Treatment & Density in the Molten State $\left(\mathbf{g} / \mathbf{c m}^{\mathbf{3}}\right){ }^{*}$ \\
\hline HPF 15\% & $1.176 \pm 0.003$ \\
HPF 25\% & $1.174 \pm 0.002$ \\
HPF 35\% & $1.179 \pm 0.002$ \\
\hline
\end{tabular}

* The number of replicas was 3.

Table 5 shows the values of humidity, extrusion temperature, and percentage of hydrolyzed protein flour of the 27 treatments studied and the values of adjustment of their rheological behavior to the models of Law of Power, Casson, and Bingham. The coefficient of determination $\left(R^{2}\right)$ and the standard error (E.M) were determined for each model.

Table 5 presents three models of rheological behavior according to different processing conditions. The standard error is observed for each model, where the lowest values correspond to the Power Law model, mainly due to lower hydrolyzed flour content (15\%). Therefore, this is the model that best fits the behavior of the experimental data. The coefficients of determination and standard error for the Casson and Bingham models that incorporate the term $\tau_{\text {or }}$ have the slightest adjustment concerning the experimental values. The Power Law model predominates in the analysis of viscosity behavior in extrusion processes [17]. Similar studies with mixtures of soybeans and corn for animal feed obtained a better fit with the Power Law model [18]. Other studies evaluated yield stress $\left(\tau_{\text {or }}\right)[20,21]$, described in the Herschel-Bulkley model, obtaining as a result that this parameter is related to a structuring of the material, possibly by the presence of semicrystalline structures. However, crystals could be unstructured during the shear treatment before the viscosity measurement, generating controversy regarding the results. Some authors recommend complementing the analysis with X-ray diffraction to observe changes in crystallinity [22]. 
In any of the cases reported above, the information was finally interpreted by the Power Law model, which for the case study was the one that presented the best fit, verified by the values of $\mathrm{R}^{2}$ and E.M. Similarly, Harper's rheological model, which explains the behavior of extruded polymeric matrices, assumes for its use that the flow must be fully developed and that the fluid behaves according to the Power Law $[7,23]$.

Table 5. Coefficient of determination $\left(R^{2}\right)$ and standard error (E.M) values of the Power Law, Casson, and Bingham models.

\begin{tabular}{|c|c|c|c|c|c|c|c|c|c|}
\hline \multirow[b]{3}{*}{ Sample } & \multirow{2}{*}{\multicolumn{2}{|c|}{ Treatments }} & \multirow[b]{3}{*}{ HPF (\%) } & \multicolumn{6}{|c|}{ Mathematical Model } \\
\hline & & & & \multicolumn{2}{|c|}{ Power Law } & \multicolumn{2}{|c|}{ Casson } & \multicolumn{2}{|c|}{ Bingham } \\
\hline & $\begin{array}{c}\text { Moisture } \\
(\%)\end{array}$ & $\begin{array}{c}\text { Temperature } \\
\left({ }^{\circ} \mathrm{C}\right)\end{array}$ & & $\mathbf{R}^{2}$ & E.M & $\mathbf{R}^{2}$ & E.M & $\mathbf{R}^{2}$ & E.M \\
\hline $\mathrm{T} 1$ & 20 & 115 & 15 & 0.981 & 0.828 & 0.985 & 1.124 & 0.989 & 4.586 \\
\hline $\mathrm{T} 2$ & 22 & 115 & 15 & 0.952 & 1.938 & 0.943 & 1.803 & 0.934 & 3.600 \\
\hline T3 & 24 & 115 & 15 & 0.950 & 2.052 & 0.946 & 2.010 & 0.942 & 5.920 \\
\hline $\mathrm{T} 4$ & 20 & 125 & 15 & 0.994 & 0.523 & 0.997 & 0.617 & 0.998 & 1.956 \\
\hline $\mathrm{T} 5$ & 22 & 125 & 15 & 0.995 & 0.675 & 0.996 & 0.892 & 0.996 & 2.040 \\
\hline T6 & 24 & 125 & 15 & 0.999 & 2.315 & 0.999 & 2.550 & 1.000 & 2.441 \\
\hline $\mathrm{T} 7$ & 20 & 135 & 15 & 0.989 & 1.017 & 0.989 & 1.133 & 0.990 & 0.759 \\
\hline $\mathrm{T} 8$ & 22 & 135 & 15 & 0.985 & 0.607 & 0.982 & 0.566 & 0.979 & 0.508 \\
\hline T9 & 24 & 135 & 15 & 0.978 & 6.561 & 0.979 & 6.258 & 0.980 & 3.040 \\
\hline $\mathrm{T} 10$ & 20 & 115 & 25 & 0.976 & 5.185 & 0.974 & 5.409 & 0.972 & 61.313 \\
\hline $\mathrm{T} 11$ & 22 & 115 & 25 & 0.999 & 6.627 & 0.999 & 7.134 & 0.999 & 41.409 \\
\hline $\mathrm{T} 12$ & 24 & 115 & 25 & 0.957 & 4.080 & 0.960 & 4.701 & 0.962 & 20.725 \\
\hline $\mathrm{T} 13$ & 20 & 125 & 25 & 0.994 & 8.089 & 0.994 & 8.573 & 0.993 & 58.775 \\
\hline $\mathrm{T} 14$ & 22 & 125 & 25 & 0.986 & 5.626 & 0.985 & 5.782 & 0.983 & 24.038 \\
\hline T15 & 24 & 125 & 25 & 0.978 & 4.338 & 0.977 & 4.587 & 0.977 & 9.310 \\
\hline $\mathrm{T} 16$ & 20 & 135 & 25 & 0.981 & 9.473 & 0.981 & 10.147 & 0.981 & 33.067 \\
\hline $\mathrm{T} 17$ & 22 & 135 & 25 & 0.986 & 5.814 & 0.986 & 5.905 & 0.985 & 13.208 \\
\hline $\mathrm{T} 18$ & 24 & 135 & 25 & 0.997 & 3.932 & 0.997 & 4.104 & 0.997 & 0.635 \\
\hline T19 & 20 & 115 & 35 & 0.965 & 5.103 & 0.958 & 5.792 & 0.951 & 176.116 \\
\hline $\mathrm{T} 20$ & 22 & 115 & 35 & 0.940 & 2.596 & 0.932 & 2.865 & 0.924 & 99.746 \\
\hline $\mathrm{T} 21$ & 24 & 115 & 35 & 0.996 & 2.292 & 0.994 & 2.578 & 0.991 & 79.431 \\
\hline $\mathrm{T} 22$ & 20 & 125 & 35 & 0.981 & 3.976 & 0.979 & 4.647 & 0.976 & 145.233 \\
\hline $\mathrm{T} 23$ & 22 & 125 & 35 & 0.965 & 2.693 & 0.969 & 3.150 & 0.972 & 98.550 \\
\hline $\mathrm{T} 24$ & 24 & 125 & 35 & 0.946 & 2.334 & 0.952 & 2.557 & 0.956 & 66.145 \\
\hline $\mathrm{T} 25$ & 20 & 135 & 35 & 1.000 & 3.632 & 0.999 & 4.140 & 0.998 & 95.237 \\
\hline $\mathrm{T} 26$ & 22 & 135 & 35 & 0.958 & 2.411 & 0.965 & 2.816 & 0.971 & 58.995 \\
\hline $\mathrm{T} 27$ & 24 & 135 & 35 & 0.991 & 2.341 & 0.992 & 2.627 & 0.992 & 49.114 \\
\hline
\end{tabular}

Under the conditions of this experiment, the mixture presented a pseudoplastic behavior with a decrease in apparent viscosity as the shear rate increased, as indicated by the value of $n$ in the Power Law model. Various authors [10,24-26] reported the use of the Power Law model to describe flow behavior using in-line and off-line rheology and experimental conditions similar to the present experiment. Similar studies investigated the rheological behavior of a formulation for animal feed [18]. They studied the rheological behavior of mixtures of native and pregelatinized wheat starch. These results indicate that the rheological behavior of the treatments is determined by the properties of starch, the majority component of the formulations [24]. The dependence of the viscosity of the molten polymer on the velocity is related to the molecular reduction at the higher shear rate, and the further away the value of $n$ id from 1 , the further away it moves away from a behavior of a Newtonian fluid, being more sensitive to the shear rate [10,13]. According to the Power Law model, the analysis of variance was performed for the response variables $n$ and $K_{l p}$, as shown in Table 6.

According to the assumptions of normality, the values of $\mathrm{F}$ and $\mathrm{P}$ estimated in the ANOVA $(p<0.05)$ indicate that the factors hydrolyzed protein flour, temperature, and humidity have a significant influence on the values of $n$ and $\mathrm{k}$, being the hydrolyzed protein flour the aspect of most significant impact. 
Table 6. Analysis of variance model of Power Law.

\begin{tabular}{ccccc}
\hline \multirow{2}{*}{ Fountain } & \multicolumn{2}{c}{$\boldsymbol{n}$} & \multicolumn{2}{c}{$\boldsymbol{K}_{\boldsymbol{l p}} \mathbf{( P a \cdot \mathbf { s } ^ { \mathbf { n } } )}$} \\
\cline { 2 - 5 } & $\mathbf{F}$ & $\mathbf{P}$ & $\mathbf{F}$ & $\mathbf{P}$ \\
\hline Moisture & 159.39 & 0.000 & 317.33 & 0.000 \\
Temperature & 251.89 & 0.000 & 506.18 & 0.000 \\
HPF & 1470.92 & 0.000 & 2355.22 & 0.000 \\
Moisturex $\times$ Temperature & 1.46 & 0.242 & 19.53 & 0.000 \\
Moisture $\times$ HPF & 7.34 & 0.000 & 105.57 & 0.000 \\
Temperature $\times$ HPF & 4.54 & 0.006 & 175.12 & 0.000 \\
Moisture $\times$ Temperature $\times$ HPF & 1.42 & 0.233 & 8.24 & 0.000 \\
\hline
\end{tabular}

Table 7 shows the mean values and standard deviation of flow behavior index $(n)$ and consistency index $\left(K_{l p}\right)$ for the treatments studied. The mean comparison test $(p<0.05)$ shows 13 different groups for the variable flow behavior index $(n)$. It is observed that in all cases, the treatments are affected by temperature, humidity, and the content of hydrolyzed protein flour.

Table 7 shows that as the percentage of humidity and temperature increases, the value of $n$ increases, and the importance of $K_{l p}$ decreases. Both the rise in water and the temperature rise reduces the resistance to the flow of the matrices. Conversely, when the percentage of hydrolyzed flour in the formulation increases, the value of $n$ becomes lower, and the importance of $K_{l p}$ increases. This fact may be because hydrolyzed proteins (despite having a plasticizing effect due to their low molecular weight) could also be part of the continuous matrix when unfolding and interacting with other proteins or starch, thereby increasing the consistency index [27] going from values between 159 and $982 \mathrm{~Pa} \cdot \mathrm{s}^{\mathrm{n}}$ for $15 \%$ of protein flour, to values between 1014 and $6362 \mathrm{~Pa} \cdot \mathrm{s}^{\mathrm{n}}$ for $35 \%$ of protein flour. This behavior has a close relationship with the amphipathic properties of proteins, according to the amino acid composition of hydrolyzed protein flour [28-30].

The treatments T9 and T18, described in Table 7 letter (a) parameter $n$, letter (j) parameter $K_{l p}$, presented the highest values of $\mathrm{n}$ and close to 1 , as well as the lowest values of $K_{l p}$, which indicates a behavior that approaches a Newtonian fluid, being the treatments that have higher moisture and temperature content. The moisture content combined with the increase in temperature increased mobility in the extrusion barrel [31], behavior reflected in the value of $K_{l p}$. Treatments 19 and 20 [letters $(k, 1)$ parameter $n$ and letters $(\mathrm{a}, \mathrm{b})$ parameter $\mathrm{k}$ ], show the lowest $n$ values of the experiment, as well as the highest values of $K_{l p}$, corresponding to the treatments with higher content of hydrolyzed protein flour, indicating the presence of crosslinking interactions that will influence pseudoplastic behavior, an effect marked by the increase in the incorporation of hydrolyzed protein flour, which contributes to the stability of the final product forming networks of intermolecular bonds such as hydrogen and ionic bonds [30], presenting the lowest values of $n$ and the highest value of k. Studies reported values of $n=0.246$ [3] in extruded diets for fish with high protein content, indicating a high degree of thinning by shear. Similar behavior reported that an increase in protein in the formulation decreases the value of $n$, which is behavior similar to that obtained in the present study [16].

Table 8 shows the parameters of Harper's model. The equation presents the assumption that the apparent viscosity $(n)$ has a dependence on the Power Law with the shear rate, an Arrhenius dependence on temperature (T), and an exponential dependence on moisture content $(\mathrm{MC}) \gamma[3]$, assuming that the flow is fully developed through the capillary and is in laminar regime, there is no viscous dissipation or slippage of the material in the wall, there is no loss of pressure at the end of the capillary, and the fluid behaves according to the Power Law $[7,23]$. 
Table 7. Mean values and standard deviation of flow behavior index $(n)$ and consistency index $\left(K_{l p}\right)$ for the studied treatments.

\begin{tabular}{ccc}
\hline Sample & Flow Behavior Index $(n)$ & Consistency Index $\left(\boldsymbol{K}_{l \boldsymbol{p},}, \mathbf{P a} \cdot \mathbf{s}^{\mathbf{n}}\right)$ \\
\hline T1 & $0.6108 \pm 0.0009^{\mathrm{h}}$ & $982 \pm 10^{\mathrm{e}}$ \\
T2 & $0.72 \pm 0.04^{\mathrm{e}}$ & $868 \pm 14^{\mathrm{f}}$ \\
T3 & $0.743 \pm 0.009^{\mathrm{d}}$ & $561 \pm 29^{\mathrm{g}}$ \\
T4 & $0.67 \pm 0.03^{\mathrm{f}}$ & $535 \pm 23^{\mathrm{g}}$ \\
T5 & $0.74 \pm 0.03^{\mathrm{d}}$ & $408 \pm 57^{\mathrm{h}}$ \\
T6 & $0.82 \pm 0.02^{\mathrm{b}}$ & $322 \pm 27^{\mathrm{i}}$ \\
T7 & $0.79 \pm 0.02^{\mathrm{c}}$ & $333 \pm 20^{\mathrm{i}}$ \\
T8 & $0.849 \pm 0.005^{\mathrm{b}}$ & $176 \pm 2^{\mathrm{j}}$ \\
T9 & $0.976 \pm 0.012^{\mathrm{a}}$ & $159 \pm 9^{\mathrm{j}}$ \\
T10 & $0.62 \pm 0.02^{\mathrm{g}}$ & $1474 \pm 132^{\mathrm{e}}$ \\
T11 & $0.68 \pm 0.02^{\mathrm{f}}$ & $992 \pm 81^{\mathrm{e}}$ \\
T12 & $0.73 \pm 0.03^{\mathrm{d}}$ & $585 \pm 99^{\mathrm{g}}$ \\
T13 & $0.673 \pm 0.009^{\mathrm{f}}$ & $1087 \pm 49^{\mathrm{e}}$ \\
T14 & $0.71 \pm 0.03^{\mathrm{e}}$ & $677 \pm 108^{\mathrm{g}}$ \\
T15 & $0.800 \pm 0.013^{\mathrm{b}}$ & $334 \pm 22^{\mathrm{i}}$ \\
T16 & $0.76 \pm 0.02^{\mathrm{c}}$ & $666 \pm 66^{\mathrm{g}}$ \\
T17 & $0.81 \pm 0.03^{\mathrm{b}}$ & $431 \pm 69^{\mathrm{h}}$ \\
T18 & $0.885 \pm 0.006^{\mathrm{a}}$ & $207 \pm 5^{\mathrm{j}}$ \\
T19 & $0.372 \pm 0.012^{\mathrm{m}}$ & $6362 \pm 371^{\mathrm{a}}$ \\
T20 & $0.381 \pm 0.007^{\mathrm{l}}$ & $4472 \pm 142^{\mathrm{b}}$ \\
T21 & $0.441 \pm 0.004^{\mathrm{k}}$ & $2299 \pm 43^{\mathrm{d}}$ \\
T22 & $0.393 \pm 0.003^{\mathrm{l}}$ & $4125 \pm 69^{\mathrm{b}}$ \\
T23 & $0.42 \pm 0.02^{\mathrm{k}}$ & $2983 \pm 302^{\mathrm{c}}$ \\
T24 & $0.458 \pm 0.013^{\mathrm{k}}$ & $2188 \pm 147^{\mathrm{d}}$ \\
T25 & $0.47 \pm 0.02^{\mathrm{j}}$ & $2453 \pm 290^{\mathrm{c}}$ \\
T26 & $0.554 \pm 0.003^{\mathrm{i}}$ & $1542 \pm 103^{\mathrm{e}}$ \\
T27 & $\mathrm{j}$ & $\pm 31^{\mathrm{e}}$ \\
\hline
\end{tabular}

Different superscript letters in the same column indicate significant differences between treatments $(p<0.05)$. The number of replicas was 5 .

Table 8. Harper's model parameters for hydrolyzed protein flour.

\begin{tabular}{|c|c|c|c|c|c|c|}
\hline $\begin{array}{c}\text { Hydrolyzed } \\
\text { Protein Flour (\%) }\end{array}$ & $\underset{\left(\mathbf{P a} \cdot \mathbf{s}^{\mathrm{n}}\right)}{\boldsymbol{K}_{l p}}$ & $n(\mathrm{~Pa} \cdot \mathrm{s})$ & $\begin{array}{l}E / R \\
(\mathrm{~K})\end{array}$ & $b$ & $\mathbf{R}^{2}$ & Equation \\
\hline 15 & 1.00 & 0.79 & 2563 & -0.82 & 0.89 & $\begin{array}{c}\eta=1.00 \times(\gamma)^{-0.21} \mathrm{e}[(2563 \times \mathrm{T})- \\
(0.82 \times \mathrm{MC})]\end{array}$ \\
\hline 25 & 359.96 & 0.65 & 1410 & -11.91 & 0.95 & $\begin{array}{c}\eta=359.96 \times(\gamma)^{-0.35} \mathrm{e}[(1410 \times \mathrm{T}) \\
-(11.92 \times \mathrm{MC})]\end{array}$ \\
\hline 35 & 1745.86 & 0.48 & 1208 & -11.82 & 0.89 & $\begin{array}{c}\eta=1745.86 \times(\gamma)^{-0.52} \mathrm{e}[(1208 \times \mathrm{T}) \\
-(11.82 \times \mathrm{MC})]\end{array}$ \\
\hline
\end{tabular}

$K_{l p}$ —consistency index; $n$-apparent viscosity; $E$-activation energy; $R$-gas constant; $b$-relates the change in moisture content to the viscosity of the material.

The models described for the different percentages of inclusion of hydrolyzed protein flour $(15,25$, and $35 \%)$ show values with a positive sign for the term $(E / R)$, indicating that the increase in viscosity is related to the decrease in the temperature of the product in the range of temperatures studied [3]. The increase in the consistency index $K_{l p}$ is related to the proportional increase of hydrolyzed protein flour, behavior possibly related to more significant interaction between the macromolecules presents in the mixture [32]. The equations show an $\mathrm{R}^{2}$ between 0.89 and 0.95 , which allows the model to fit the data and the possibility of using the equation as a data design and estimation tool under similar test conditions. 


\subsection{Effect of Temperature}

Figure 2 shows the effect of temperature variation on the shear stress and apparent viscosity in the treatments studied with a moisture content of $22 \%$. The shear stress and apparent density have an opposite behavior compared to the shear rate, and as the temperature increases, the shear stress and the evident viscosity decrease. It is known that an increase in temperature results in a reduction of the viscosity of the molten polymer $[13,14,21]$. During the extrusion process, polymers such as starch and protein can present different degrees of transformation and molecular degradation under a thermomechanical treatment, such as extrusion cooking [33]. It is reported that the increase in speed can reduce viscosity, and although the average residence time is reduced, the intensity of mechanical treatment, transformation, and macromolecular degradation increases, and therefore, results in lower viscosity in a molten state, being more critical at a lower temperature [15].

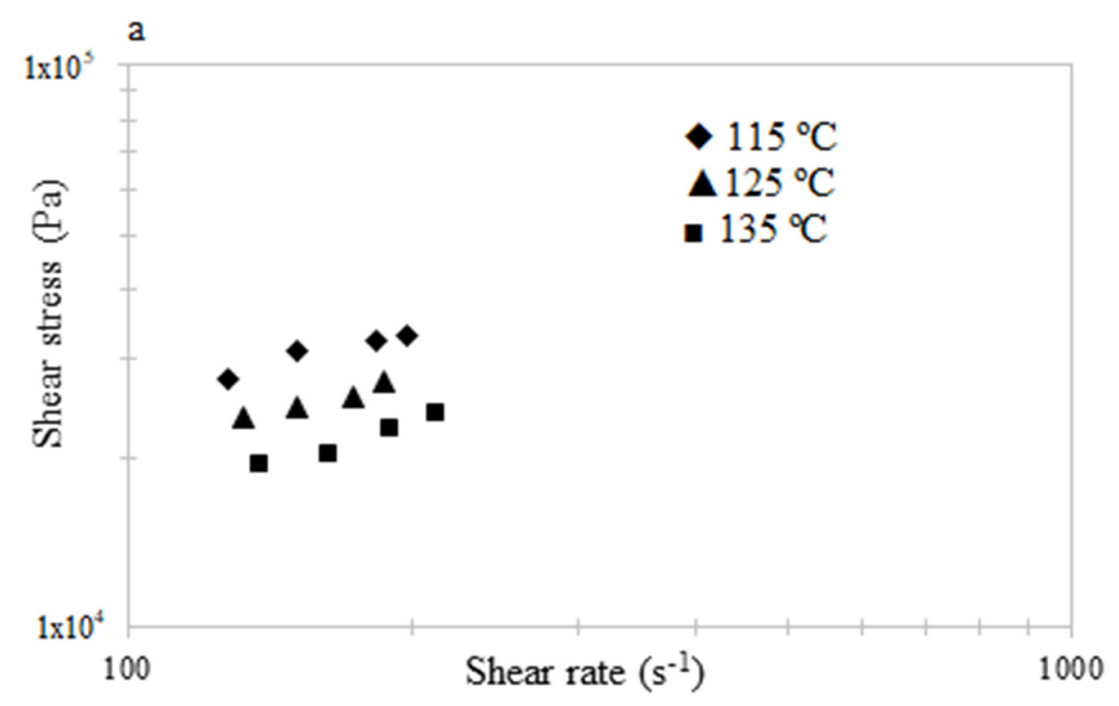

$\mathrm{b}$

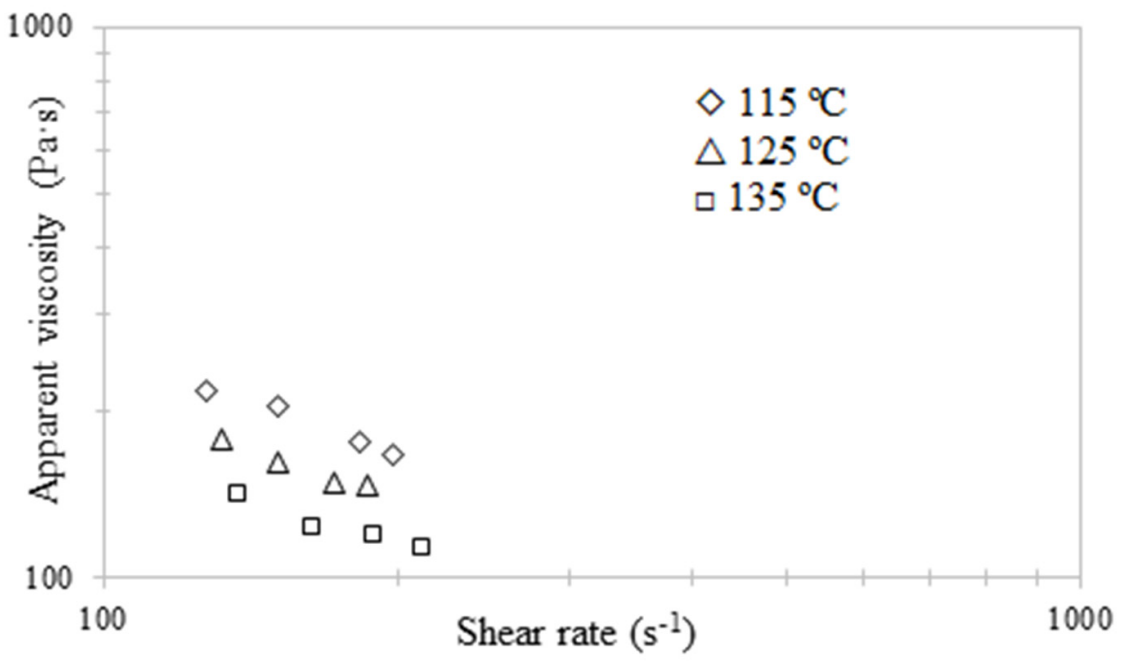

Figure 2. Effect of temperature variation on shear stress (a) and apparent viscosity (b) in the treatments studied with a moisture content of $22 \%$ and $35 \% \mathrm{HPF}$.

Increasing the temperature increases the molecular degradation, decreasing its size and growing mobility by increasing kinetic energy and reducing the volume occupied by each molecule [34]. Similarly, an increase in temperature generates an increase in the gelatinization of starch [10]. Usually, this would lead to an increase in viscosity. However, 
in the analyzed treatments, it is observed that the viscosity decreases, suggesting that the effect of molecular degradation and the increase in kinetic energy are more significant than gelatinization on the change in thickness, as shown in Figure 2.

The temperatures used in the extrusion process led to denaturation of proteins due to the irreversible alteration of non-covalent interactions (hydrophobic and electrostatic), wherein the secondary, tertiary, and quaternary structures of the proteins will weaken due to temperature and shear forces [34]. The proteins will unfold and align as the material travels through the extruder screw and the head [27]. As shown in Table 7, the value of $n$ approaches one at a higher temperature, behavior attributed to a decrease in the size of starch and protein molecules generated by fractionation at high temperatures [11].

Similar studies identified the effect of two different extrusion cooking (CE) conditions, milder and more severe, on the gelatinization of starch, the dough's rheological properties, and the techno-functional parameters of lentil flour. The results showed that the extruded flours also showed a lower degree of starch retrogradation than the native flour, in which they reported that the high speed of the screw has a negative effect on gelatinization, decreasing the initial viscosity and increasing the maximum viscosity of the flours extruded into a viscoamylographic profile. Therefore, the high shear causes starch degradation with the melting of the crystals of amylopectin molecules and dextrinization [12].

\subsection{Effect of Humidity}

Figure 3 shows the effect of moisture content variation on the shear stress and apparent viscosity in the treatments studied with a protein flour content of $35 \%$. It is observed that the increase in moisture content caused a decrease in both shear stress and apparent viscosity.

According to Table 7, when the moisture content decreases from $24 \%$ to $20 \%$, the consistency index $\left(K_{l p}\right)$ increases from values between 159 and $2299 \mathrm{~Pa} \cdot \mathrm{s}$ to values between 333 and $6362 \mathrm{~Pa} \cdot \mathrm{s}$., indicating that the moisture affects the apparent viscosity of the treatments. Similar results were found where researchers studied the effect of the extrusion parameters on the rheological behavior of corn using an in-line slit die rheometer, reporting that the viscosity, specific mechanical energy, torque, and pressure in the head decreased with increasing humidity of the matrices, consistent with an increase in the molecular mobility of the treatments $[10,13]$. On the other hand, it is expected that at lower moisture contents, both starch molecules and proteins suffer more damage, destructuring the molecules causing Maillard reactions, minimizing this effect at moisture contents higher than $25 \%$ [27].

The gelatinization of starch during extrusion occurs at a humidity lower than $30 \%$, lower than other ways of processing food [35]. The limitation of the water proportion between $20 \%$ and $24 \%$ in the extrusion-cooking process, conditions in which the present test was developed, affected the macromolecules present in the processed mixture, possibly obtaining starch molecules in different gelatinization stages, such as gelatinized but not swollen granules, swollen and gelatinized granules, and even wholly damaged granules. Therefore, the interaction between moisture content and temperature affects molecular transformation at different levels [36]. An increase in the moisture content and the extrusion temperature promotes molecular mobility, with the corresponding decrease in viscosity, as shown in Figure 3. On the other hand, the temperature increases the system's energy, the water acts as a solvent, and the plasticizer makes it easy for macromolecules to unfold $[11,17,25,36]$. 
a

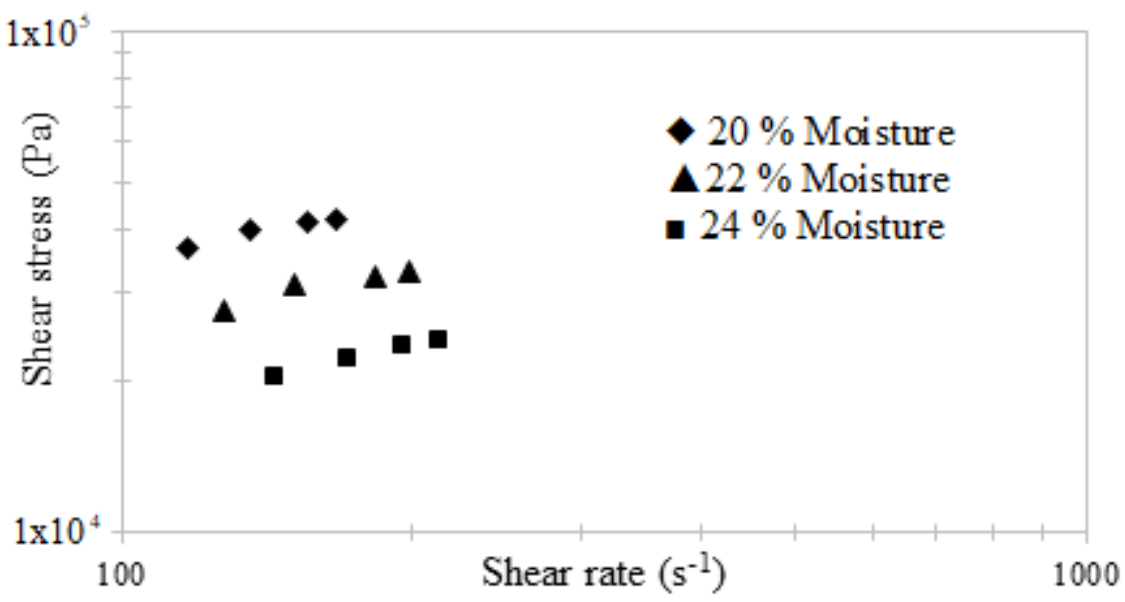

$\mathrm{b}$

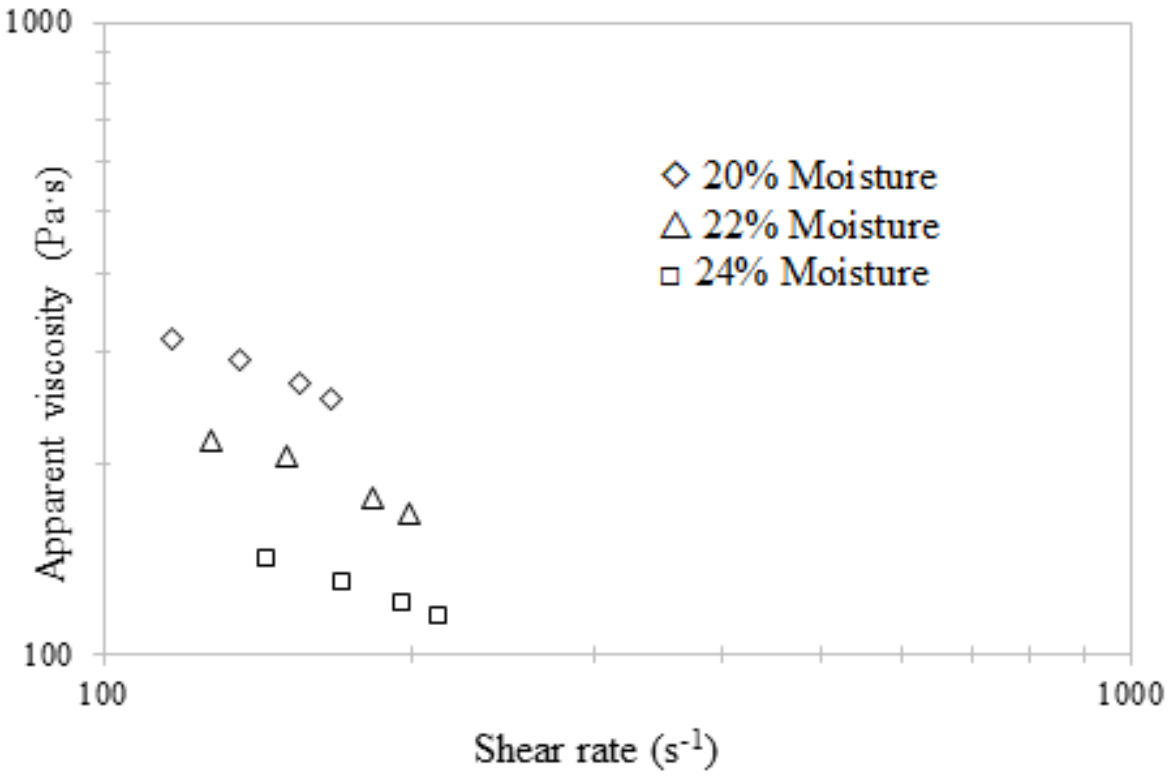

Figure 3. Effect of the moisture content variation on the shear stress (a) and apparent viscosity (b) in the treatments studied with a protein flour content of $35 \%$ and $115^{\circ} \mathrm{C}$.

Other studies investigated the structural and rheological changes of textured mung bean protein induced by feed moisture during extrusion. They found that extrusion at $49.3 \%$ feed moisture favorably produced partially denatured textured mung bean protein (TMBP), the formation of small aggregates, better solubility, and digestibility with a strong gel formation behavior, while the moisture content of $30.0-60.0 \%$ resulted in a complete denaturation of the protein and undesirable formation of large aggregates and weak gels [37]. Furthermore, both amylose and amylopectin could significantly reduce pressure and torque during the high humidity extrusion process, further decreasing the extrudates' color difference $(\Delta \mathrm{E})$, hardness, elasticity, and chewiness [38].

\subsection{Effect of Hydrolyzed Protein Flour}

Enzymatic hydrolysis in the starches is important as it offers the environment more favorable breakdown conditions and does not involve solvents or chemical reagents. It leads to significant changes in the functional properties of starches, which is essential in defining the industrial use of starches. The enzymatically hydrolyzed starches have lower 
paste viscosities and swelling power, thus influencing the functional characteristics of the flour [39].

Figure 4 shows the effect of the variation of the hydrolyzed protein flour content on the shear stress and apparent viscosity at $125^{\circ} \mathrm{C}$. Therefore, as the shear rate increases, the shear stress increases, and the viscosity decreases. Furthermore, as the amount of hydrolyzed flour in the formulation increases, the shear stress and viscosity values tend to grow. Due to the low molecular weight of the peptides from hydrolyzed protein flour, it could be inferred that they tend to be located between the starch chains, acting both as plasticizers of the matrix and as crosslinking agents between the different extrudate fractions (free sugars, dextrins, peptides of various molecular weights) [30]. Starch, for its part, as the main component in the evaluated matrix $(52 \%)$ interacts directly with proteins since they contain several hydrophilic groups such as $-\mathrm{OH},-\mathrm{NH}_{2},-\mathrm{COOH}$, and $-\mathrm{SH}$ in the side alkyl chains, which can form bonds with starch, affecting the rheological properties of the material [40]. Generally, an increase in hydrolyzed protein slightly increases the viscosity, as shown in Figure 4.
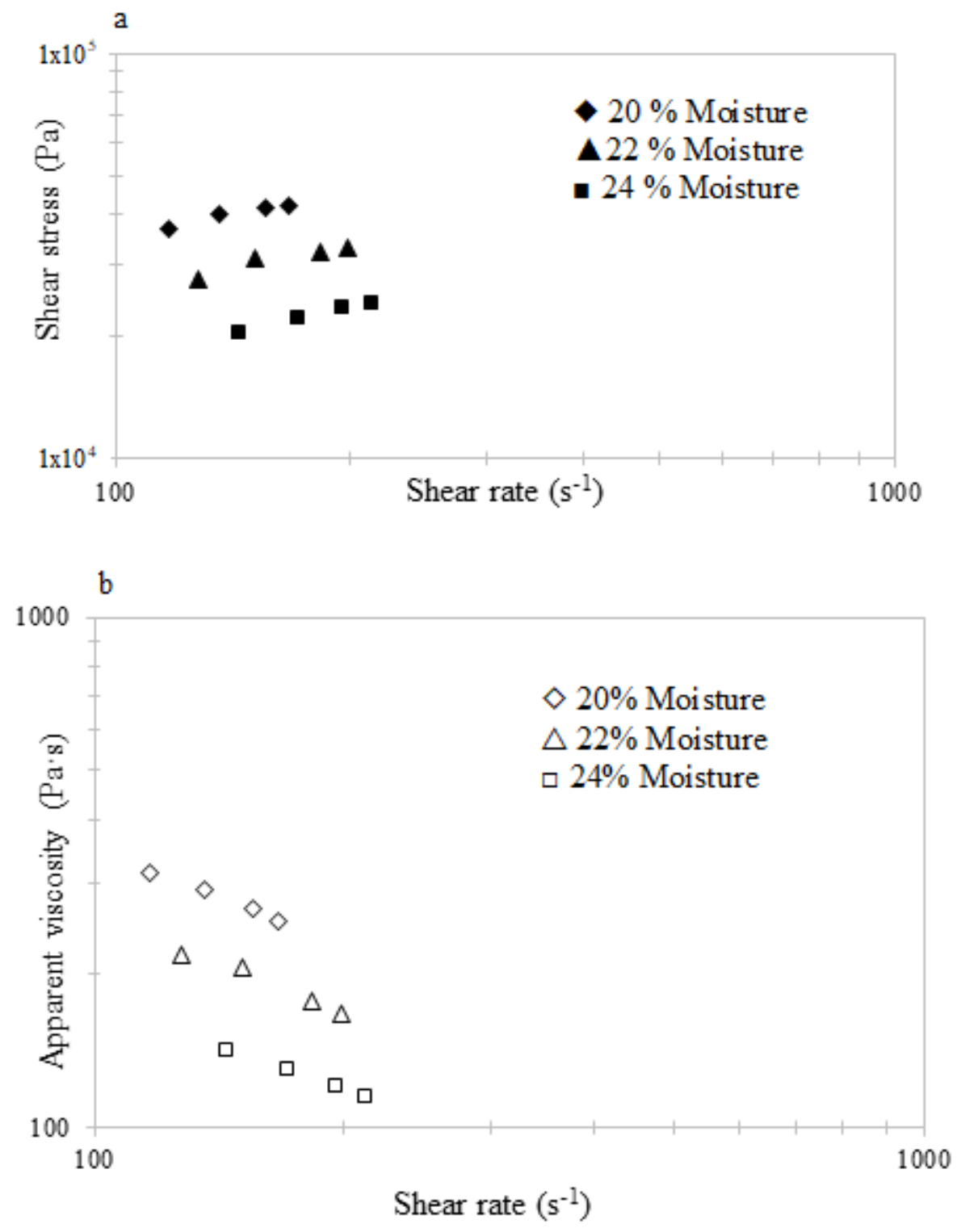

Figure 4. Effect of variation in hydrolyzed protein flour content on shear stress (a) and apparent viscosity (b) at $125^{\circ} \mathrm{C}$ and $22 \%$ moisture. 
Within hydrolyzed protein flour content, as shown in Figure 4, peptides that promote the sliding of starch chains would act as plasticizers, while peptides with exposed amino acid residues with the ability to react with dextrin and sugar end groups would act as crosslinking agents, reducing molecular mobility and therefore generating a viscosity increase [30], according to the results obtained. The increase in viscosity of the treatments studied suggests that crosslinking has a more significant effect on the viscosity of the treatments than the possible plasticizing effect of the low molecular weight peptides, which would also be consistent with the increase in shear stress promoted by the rise [40-43].

Similar studies reported the increase in viscosity due to gel formation under extrusion conditions, related to the denaturation of myosin, mainly responsible for gelation, aggregation, and various forms of interaction phenomena [42,44], forming a three-dimensional network that the terminal groups of the molecules can establish via hydrophobic interactions, as well as disulfide bridges. The exposed hydrophilic amino acid residues are free to interact and react with the other components, such as sugar residues and the aqueous medium. In contrast, the hydrophobic amino acid residues align, forming intermolecular hydrophobic bonds, trapping apolar molecules, such as lipids or air present in formulations, inside [27]. The protein-starch interactions due to the formation of amylose-protein complexes [45,46], the number of insoluble aggregates formed [46], as well as the crosslinking of the peptides during Maillard reactions [41], could affect increasing the viscosity and resistance to the flow of the material, requiring greater torque during the extrusion process with the addition of hydrolyzed protein flour. Additionally, researchers studied the effect of the expansion of salt and sugar on the extrusion process of wheat and corn mixtures and reported that when the interactions between macromolecules (starch chains) were improved, the viscosity of the melt required a more significant amount of energy to push the molten matrix through the screw and this, in turn, generated more considerable pressure in the head [46].

Other authors studied the shear-induced improvement of the techno-functional properties of whole meal flours by extrusion. The extruded whole flours produced under high shear showed the disappearance of the viscosity peak when hot with a significant increase in the apparent viscosity when cold. Furthermore, an improvement in the hydration properties was shown due to the modification of the starch molecules and the dietary fiber fractions after applying the selected extrusion conditions. This study suggests that the cold gelling capacity of extruded flours produced with cereals and legumes is promising. This property could be useful in various food systems to develop a wide variety of products [43].

According to the above, it is possible to infer that the increase in the concentration of hydrolyzed protein generates an increase in the interactions of the macromolecules present through the crosslinking of polymeric chains and the presence of high molecular weight proteins contained in fishmeal. Conventional water lowers the free water in the system by forming aggregates, as discussed above. Similar results studied the effect of hydrolyzed fish muscle on the rice flour extrusion process, observing that its addition tends to increase the values of specific mechanical energy slightly, attributing this phenomenon to the presence of low molecular weight peptides that cause compaction during extrusion, increasing energy requirements per unit of extruded mass $[47,48]$. When the mixture is exposed to thermomechanical treatments such as extrusion, the protein may experience an unfolding of packed structures or separation of the protein into subunits [46], aggregation [34], and crosslinking [32], behavior related to the increase in shear stress, as observed in the results described above.

\section{Conclusions}

The slit dies to type in-line rheometer allowed to assess the rheological behavior of the material, obtaining information on the actual processing condition, observing that the evaluated treatments conform to the Power Law, where an increase in the shear rate decreases the viscosity of the material, corresponding to a pseudoplastic behavior. The incorporation of hydrolyzed protein flour has a significant effect on the value of $\mathrm{n}$ and $K_{l p}$, 
increasing the viscosity with the increase in the percentage of inclusion of HPF, suggesting the formation of a series of crosslinking reactions, formation of three-dimensional networks, hydrophobic bonds, and Maillard reactions, with response in process variables such as the increase in specific mechanical energy. The models obtained to predict the viscosity are adjusted to the system's changes in sheer speed, temperature, and humidity.

Author Contributions: Conceptualization, R.O.-T.; Data curation, J.L.H.-C.; Formal analysis, J.L.H.C.; Funding acquisition, J.L.H.-C.; Investigation, J.L.H.-C.; Methodology, J.L.H.-C.; Project administration, J.L.H.-C. and H.S.V.-C.; Resources, J.L.H.-C., H.S.V.-C., and A.F.-Q.; Software, J.L.H.-C. and R.O.-T.; Supervision, H.S.V.-C. and A.F.-Q.; Validation, J.L.H.-C., H.S.V.-C., and A.F.-Q.; Visualization, J.L.H.-C. and A.F.-Q.; Writing—original draft, J.L.H.-C. and R.O.-T.; Writing-review and editing, J.L.H.-C. and R.O.-T. All authors have read and agreed to the published version of the manuscript.

Funding: This research was funded by SISTEMA GENERAL DE REGALIAS-COLOMBIA, project number BPIN 2012000100137 and The APC was funded by UNIVERSIDAD DEL CAUCA.

Institutional Review Board Statement: Not applicable.

Informed Consent Statement: Not applicable.

Data Availability Statement: The study did not report any data.

Acknowledgments: The authors thank the Universidad Nacional del Cauca, Universidad del Valle and the Universidad de Cartagena (Colombia) to support the development of this work regarding laboratory, software use, and time for their researchers.

Conflicts of Interest: The authors declare they have no conflicts of interest.

\section{References}

1. Mercier, C.; Linko, P.; Harper, J.M. Extrusion Cooking; American Association of Cereal Chemists: St. Paul, MN, USA, 1989.

2. Roberts, I. In-line and on-line rheology measurement. In Instrumentation and Sensors for the Food Industry, 2nd ed.; Woodhead Publishing Limited: Sawston, UK, 2001. [CrossRef]

3. Lam, C.D.; Flores, R.A. Effect of Particle Size and Moisture Content on Viscosity of Fish Feed. Cereal Chem. 2003, 80, 20-24. [CrossRef]

4. Choudhury, G.S.; Gogoi, B.K. Extrusion processing of fish muscle: A review. J. Aquat. Food Prod. Technol. 1996, 4, 37-67. [CrossRef]

5. Van Den Einde, R.M. Molecular breakdown of corn starch by thermal and mechanical effects. Carbohydr. Polym. 2004, 56, 415-422. [CrossRef]

6. Meuser, F.; Vonlengerich, B.; Kohler, F. The influence of extrusion parameters on the functional-properties of wheat-starch. Starke 1982, 34, 366-372. [CrossRef]

7. Sandoval, A.P.; Farhat, I.; Fernández, A. Rheological modeling of cassava (Manihot esculenta Cranz) starches and flours during extrusion process. Vitae 2007, 14, 6-15.

8. Bhattacharya, S.; Das, H.; Bose, A.N. Rheological behaviour during extrusion of blends of minced fish and wheat flour. J. Food Eng. 1992, 15, 123-137. [CrossRef]

9. Harper, J.M. Extrusion of Foods; CRC Press: Boca Raton, FL, USA, 1981; pp. 3-6.

10. Li, P.X.; Campanella, O.H.; Hardacre, A.K. Using an In-Line Slit-Die Viscometer to Study the Effects of Extrusion Parameters on Corn Melt Rheology. Cereal Chem. 2004, 81, 70-76. [CrossRef]

11. Vergnes, B.; Della Valle, G.; Tayeb, J. A specific slit die rheometer for extruded starchy products. Design, validation and application to maize starch. Rheol. Acta 1993, 32, 465-476. [CrossRef]

12. Pasqualone, A.; Costantini, M.; Labarbuta, R.; Summo, C. Production of extruded-cooked lentil flours at industrial level: Effect of processing conditions on starch gelatinization, dough rheological properties and techno-functional parameters. LWT 2021, 147, 111580. [CrossRef]

13. Xie, F.; Halley, P.J.; Avérous, L. Rheology to understand and optimize processibility, structures and properties of starch polymeric materials. Prog. Polym. Sci. 2012, 37, 595-623. [CrossRef]

14. Martin, O.; Averous, L.; Della Valle, G. In-line determination of plasticized wheat starch viscoelastic behavior: Impact of processing. Carbohydr. Polym. 2003, 53, 169-182. [CrossRef]

15. Senouci, A.; Smith, A.C. An experimental study of food melt rheology-I. Shear viscosity using a slit die viscometer and a capillary rheometer. Rheol. Acta 1988, 27, 546-554. [CrossRef]

16. Bhattacharya, M.; Hanna, M.A. Viscosity modelling of dough in extrusion. Int. J. Food Sci. Technol. 1986, 21, 167-174. [CrossRef]

17. Xie, F.; Yu, L.; Su, B.; Liu, P.; Wang, J.; Liu, H.; Chen, L. Rheological properties of starches with different amylose/amylopectin ratios. J. Cereal Sci. 2009, 49, 371-377. [CrossRef] 
18. Fraiha, M.; Biagi, J.D.; Carlos De Oliveira Ferraz, A. Rheological behavior of corn and soy mix as feed ingredients. Ciência Technol. Aliment. 2011, 31, 129-134. [CrossRef]

19. Ralston, B.E.; Osswald, T.A. Viscosity of soy protein plastics determined by screw-driven capillary rheometry. J. Polym. Environ. 2008, 16, 169-176. [CrossRef]

20. Bastioli, C.; Bellotti, V.; Rallis, A. Microstructure and melt flow behavior of a starch-based polymer. Rheol. Acta 1994, 33, 307-316. [CrossRef]

21. Della Valle, G.; Vergnes, B.; Lourdin, D. Viscous properties of thermoplastic starches from different botanical origin. Int. Polym. Process. 2007, 22, 471-479. [CrossRef]

22. Tuladhar, T.R.; Mackley, M.R. Experimental observations and modelling relating to foaming and bubble growth from pentane loaded polystyrene melts. Chem. Eng. Sci. 2004, 59, 5997-6014. [CrossRef]

23. Akdogan, H. High moisture food extrusion. Int. J. Food Sci. Technol. 1999, 34, 195-207. [CrossRef]

24. Alavi, S.H.; Chen, K.H.; Rizvi, S.S.H. Rheological characteristics of intermediate moisture blends of pregelatinized and raw wheat starch. J. Agric. Food Chem. 2002, 50, 6740-6745. [CrossRef]

25. Padmanabhan, M.; Bhattacharya, M. Planar extensional viscosity of corn meal dough. J. Food Eng. 1993, 18, 389-411. [CrossRef]

26. Singh, N.; Smith, A.C. Rheological behaviour of different cereals using capillary rheometry. J. Food Eng. 1999, 39, 203-209. [CrossRef]

27. Camire, M.E. Protein Functionality Modification by Extrusion Cooking I. J. Am. Oil Chem. Soc. 1991, 68, 200-205. [CrossRef]

28. Guy, R. Raw materials for extrusion cooking. In Extrusion Cooking; Woodhead Publishing: Sawston, UK, 2001; pp. 5-28. [CrossRef]

29. Nelson, D.L.; Cox, M.M. Absolute Ultimate Guide for Lehninger. In Principles of Biochemistry; Macmillan: Basingstoke, UK, 2008; p. 600 .

30. Samuelsen, T.A.; Mjøs, S.A.; Oterhals, Å. Impact of variability in fishmeal physicochemical properties on the extrusion process, starch gelatinization and pellet durability and hardness. Anim. Feed Sci. Technol. 2013, 179, 77-84. [CrossRef]

31. Choudhury, G.S.; Gautam, A. Hydrolyzed Fish Muscle as a Modifier of Rice Flour Extrudate Characteristics Food Engineering and Physical Properties. Food Eng. Phys. Prop. 2003, 68, 1713-1721. [CrossRef]

32. Oterhals, Å.; Samuelsen, T.A. Plasticization effect of solubles in fishmeal. Food Res. Int. 2015, 69, 313-321. [CrossRef]

33. Lević, J.; Olivera, E.M.; Mr, Đ.; Sredanović, S.; Kokić, B. Heat treatments in animal feed processing. In Proceedings of the 2nd Workshop Feed-to-Food FP7 REGPOT-3. Extrusion Technology in Feed and Food Processing. Thematic Proceedings, Novi Sad, Serbia, 19-21 October 2010; pp. 19-21.

34. Zimonja, O. Effects of Chemical Changes of Starch and Proteins on Physical Pellet Quality in Respect to Extrusion Technology. In Proceedings of the International Conference "Fishery" Faculty of Agriculture, Belgrade-Zemun, Serbia, 27-29 May 2009.

35. Singh, S.; Gamlath, S.; Wakeling, L. Nutritional aspects of food extrusion: A review. Int. J. Food Sci. Technol. 2007, 42, 916-929. [CrossRef]

36. Fallahi, P.; Muthukumarappan, K.; Rosentrater, K.A. Functional and structural properties of corn, potato, and cassava starches as affected by a single-screw extruder. Int. J. Food Prop. 2016, 19, 768-788. [CrossRef]

37. Brishti, F.H.; Chay, S.Y.; Muhammad, K.; Ismail-Fitry, M.R.; Zarei, M.; Karthikeyan, S.; Caballero-Briones, F.; Saari, N. Structural and rheological changes of texturized mung bean protein induced by feed moisture during extrusion. Food Chem. 2021, $344,128643$. [CrossRef]

38. Chen, Q.; Zhang, J.; Zhang, Y.; Meng, S.; Wang, Q. Rheological properties of pea protein isolate-amylose/amylopectin mixtures and the application in the high-moisture extruded meat substitutes. Food Hydrocoll. 2021, 117, 106732. [CrossRef]

39. Amin, T.; Naik, H.R.; Hussain, S.Z.; Rather, S.A.; Makroo, H.A.; Dar, B.N.; Wani, S.M.; Bashir, O. Functional cake from rice flour subjected to starch hydrolyzing enzymes: Physicochemical properties and in vitro digestibility. Food Biosci. 2021, $42,101072$. [CrossRef]

40. Sopade, P.A.; Hardin, M.; Fitzpatrick, P.; Desmee, H.; Halley, P. Macromolecular interactions during gelatinisation and retrogradation in starch-whey systems as studied by rapid visco-analyser. Int. J. Food Eng. 2006, 2, 1-15. [CrossRef]

41. Lan, X.; Liu, P.; Xia, S.; Jia, C.; Mukunzi, D.; Zhang, X.; Xia, W.; Tian, H.; Xiao, Z. Temperature effect on the non-volatile compounds of Maillard reaction products derived from xylose-soybean peptide system: Further insights into thermal degradation and cross-linking. Food Chem. 2010, 120, 967-972. [CrossRef]

42. Gilleland, G.M.; Lanier, T.C.; Hamann, D.D. Covalent Bonding in Pressure-Induced Fish Protein Gels. J. Food Sci. 1997, 62, 713-733. [CrossRef]

43. Espinosa-Ramírez, J.; Rodríguez, A.; De la Rosa-Millán, J.; Heredia-Olea, E.; Pérez-Carrillo, E.; Serna-Saldívar, S.O. Shear-induced enhancement of technofunctional properties of whole grain flours through extrusion. Food Hydrocoll. 2021, 111, 106400. [CrossRef]

44. Stone, A.P.; Stanley, D.W. Mechanisms of fish muscle gelation. Food Res. Int. 1992, 25, 381-388. [CrossRef]

45. Allen, K.E.; Carpenter, C.E.; Walsh, M.K. Influence of protein level and starch type on an extrusion-expanded whey product. Int. J. Food Sci. Technol. 2007, 42, 953-960. [CrossRef]

46. Day, L.; Swanson, B.G. Functionality of protein-fortified extrudates. Compr. Rev. Food Sci. Food Saf. 2013, 12, 546-564. [CrossRef]

47. Pitts, K.F.; Favaro, J.; Austin, P.; Day, L. Co-effect of salt and sugar on extrusion processing, rheology, structure and fracture mechanical properties of wheat-corn blend. J. Food Eng. 2014, 127, 58-66. [CrossRef]

48. Choudhury, G.S.; Gautam, A. Effects of hydrolysed fish muscle on intermediate process variables during twin-screw extrusion of rice flour. LWT-Food Sci. Technol. 2003, 36, 667-678. [CrossRef] 